\title{
Perancangan Cold Storage untuk Produk Kedelai dengan Kapasitas 2410 Ton/hari
}

\author{
Anwar Ilmar Ramadhan ${ }^{1, *}$, Ery Diniardi², Mulyadi ${ }^{3}$ \\ ${ }^{1}$ Jurusan Teknik Mesin, Fakultas Teknik, Universitas Muhammadiyah Jakarta, Indonesia \\ J1. Cempaka Putih Tengah 27 Jakarta Pusat 10510 Indonesia \\ *Email: anwar.ilmar@ftumj.ac.id
}

\begin{abstract}
Air refreshing is a process of cooling the air so it can reach the temperature and humidity in accordance with the air condition requirements of a certain room that can regulate air flow and cleanliness. In the design of cold storage, the most decisive stage is when calculating the heat load that will be a reference for the designer in the compressor selection. PT. Mayekawa Indonesia in this case fulfill customer demand to design cold storage room, ante room and stuffing room with the need to freeze edamame (soybean) with capacity of 2410 ton / day. Obtained hasi calculation and analysis obtained by refrigeration load for cold storage room 12 equal to $42.63 \mathrm{~kW}$, for cold storage 13 equal to $26.23 \mathrm{~kW}$, ante room equal to $26.36 \mathrm{~kW}$, stuffing room equal to $10.76 \mathrm{~kW}$, and for room futures 1 and 2 obtained refrigeration load equal to $42.63 \mathrm{KW}$ and $26.23 \mathrm{~kW}$. So that obtained total refrigeration equal to $105.58 \mathrm{~kW}$. The selection of components in the refrigeration system is a component compressor using the application (software) My Com W version 2016 Compressor with type Recipro N62WBHE as much as 2 units ( 1 Unit as a back up) with a capacity of $113.1 \mathrm{~kW}$.
\end{abstract}

Keywords: Cold storage, refrigeration load, compresssor

\begin{abstract}
Abstrak
Penyegaran udara adalah suatu proses mendinginkan udara sehingga dapat mencapai temperature dan kelembaban yang sesuai dengan persyaratan kondisi udara dari suatu ruangan tertentu yang dapat mengatur aliran udara dan kebersihannya. Dalam perancangan cold storage ini, tahapan yang paling menentukan adalah saat perhitungan beban kalor yang akan menjadi acuan bagi perancang dalam pemilihan kompresor. PT. Mayekawa Indonesia dalam hal ini memenuhi permintaan pelanggan untuk merancang ruangan cold storage, ante room dan stuffing room dengan kebutuhan membekukan edamame (kedelai) berkapasitas 2410 ton/hari. Didapatkan hasi perhitungan dan analisa diperoleh beban refrigerasi untuk ruangan cold storage 12 sebesar $42.63 \mathrm{~kW}$, untuk cold storage 13 sebesar $26.23 \mathrm{~kW}$, ante room sebesar $26.36 \mathrm{~kW}$, stuffing room sebesar $10.76 \mathrm{~kW}$, serta untuk di ruangan future 1 dan 2 didapatkan beban refrigerasi sebesar $42.63 \mathrm{~kW}$ dan $26.23 \mathrm{~kW}$. Sehingga diperoleh total refrigerasi sebesar $105.58 \mathrm{~kW}$. Pemilihan komponen pada system refrigerasi yaitu komponen compressor menggunakan aplikasi (software) My Com W versi 2016 Kompressor dengan type Recipro N62WBHE sebanyak 2 unit (1 Unit sebagai back up) dengan kapasitas $113.1 \mathrm{~kW}$.
\end{abstract}

Kata kunci: cold storage, beban refrigerasi, kompresssor

\section{PENDAHULUAN}

Cold Storage merupakan ruang penyimpanan dengan harapan kualitas produk yang disimpan akan bertahan lebih lama. Temperatur produk yang dimasukkan seharusnya sesuai dengan temperature Cold Storage. Hal ini sering sekali diabaikan, sehingga chilling time produk tidak terpenuhi. Untuk memenuhi syarat tersebut diperlukan sebuah Cold Storage yang dapat berfungsi ganda yaitu sebagai pre-cooler dan Cold Storage [1], [2], [8].
Perkembangan teknologi di bidang refrigerasi dan pengkondisian udara mengalami kemajuan dengan pesat seiring berkembangnya zaman. Teknologi refrigerasi memberikan banyak keuntungan bagi manusia. Salah satu penggunaan sistem refrigerasi adalah manusia untuk industri penyimpanan dan pendistribusian produk diagnostik. Sehingga produk diagnostik yang disimpan dengan sistem refrigerasi tersebut dapat terjaga kualitas dan kesegarannya sampai waktu yang lama dan saat diperlukan untuk didistribusikan kepada konsumen [3], [5]. 
Pada saat ini produk diagnostik disimpan pada unit refrigerator pada temperatur $2-8^{\circ} \mathrm{C}$. Pada unit refrigerator tidak bisa menampung banyak produk diagnostik karena keterbatasan tempat. Mengingat besarnya peranan sistem refrigerasi (pendinginan) dalam industri penyimpanan produk diagnostik dan makin banyaknya produk yang dihasilkan sehingga menuntut agar produk tersebut tersimpan dalam kualitas yang baik dan jumlah yang banyak [5].

Berkembangnya teknologi dibidang refrigerasi atau pendinginan memberikan banyak keuntungan bagi kebutuhan manusia, karena bahan makanan yang disimpan dengan system refrigerasi tersebut dapat terjaga kualitas dan kesegarannya sampai beberapa minggu hingga saat diperlukan untuk diolah lebih lanjut.

Mengingat betapa komplek dan luasnya permasalahan yang terjadi pada cold storage terutama pada sistem refrigerasinya, untuk merumuskan masalah bagaimana mendesign sebuah cold storage yang efisien dan optimum terutama pada perhitungan beban kalor untuk keperluan penentuan peralatan pada sistem refrigerasi khusunya kompressor.

Tujuan dari penelitian ini adalah untuk menghitung beban pendingin pada cold storage untuk penyimpanan produk kedelai (edamame) dengan kapasitas 2410 ton per hari. Dengan diketahuinya beban pendinginan maka dapat ditentukan jenis mesin refrigerasi yang digunakan, terutama kompresor dengan basis My Com W.

\section{METODE PENELITIAN}

Metodologi atau pendekatan yang akan dilakukan adalah: Melakukan studi literatur dan melakukan analisis berdasarkan datadata awal dari penelitian sebelumnya mengenai perancangan cold storage untuk kapasitas 2410 ton/day serta pengambilan data dan simulasi perancangan perhitungan analitik dan My Com W Software.

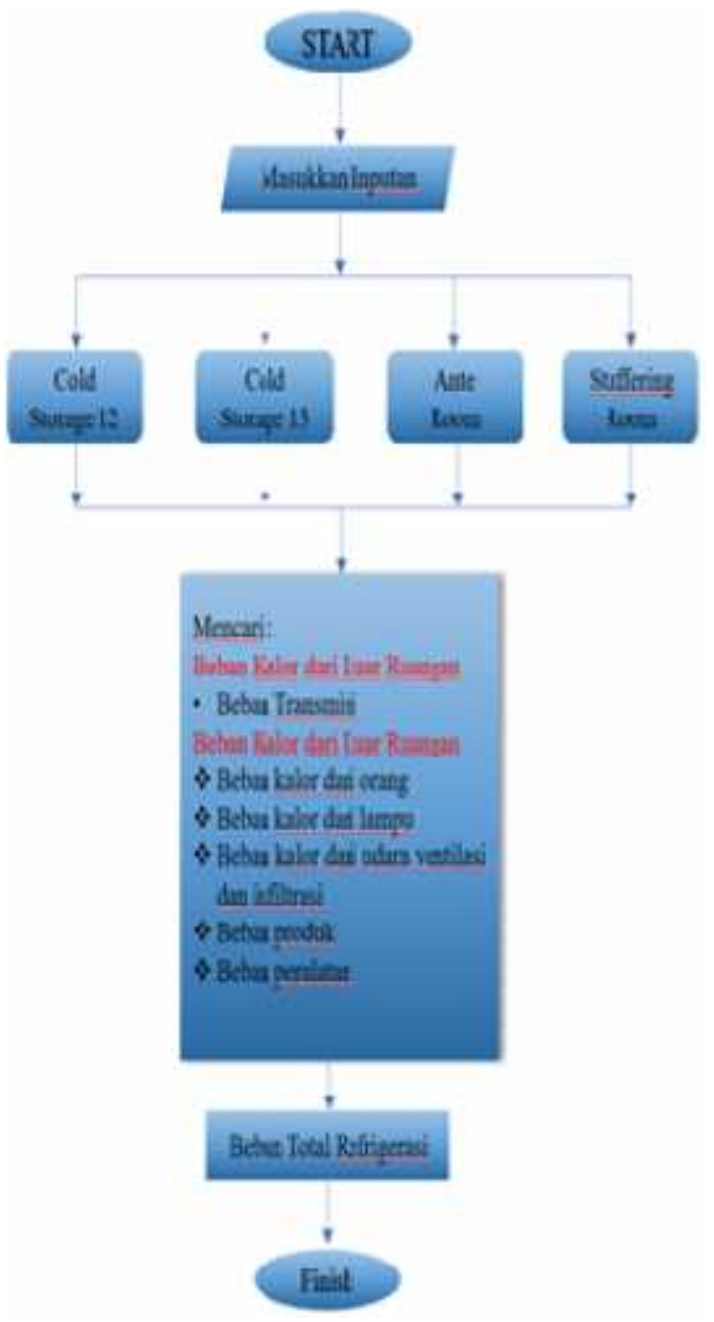

Gambar 1. Alur penelitian

Kmudian untuk mengetahui desain layout plan pada perancangan cold storage untuk kapasitas 2410 ton/day, dapat dilihat pada Gambar 2. 


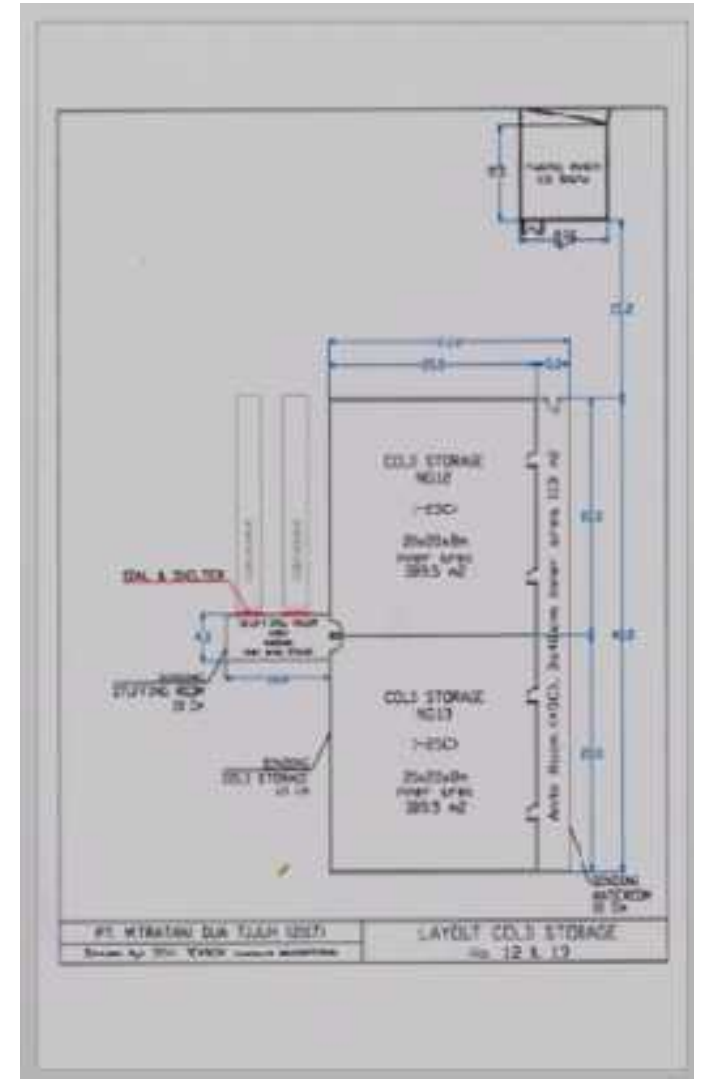

Gambar 2. Layout Plan

\section{HASIL DAN PEMBAHASAN}

Perhitungan Beban Kalor Ruangan Cold Storage (CS) 12

\subsection{Beban Kalor dari Luar Ruangan Melalui Dinding}

Dengan menggunakan persamaan (1):

qtransmisi $=$ U.A.(to-tr) $[\mathrm{kcal} / \mathrm{h}]$

$$
=(\mathrm{k} / \mathrm{d}) \text {. A. (to-tr) }[\mathrm{kcal} / \mathrm{h}]
$$

Maka, dapat dihitung beban kalor yang melalui masing-masing dinding ruangan yang diisolasi dengan bahan polyurethane yang memiliki nilai $\mathrm{k}=0,018\left[\mathrm{kcal} / \mathrm{m} . \mathrm{h} .{ }^{\circ} \mathrm{C}\right]$. Dengan ketebalan dinding insulasi $150 \mathrm{~mm}$ untuk tiap sisi maka:

a. qtransmisi Atap

$$
=\quad(0,018 / 0,15) \cdot(19 \cdot 3 \times 20) \cdot(45-
$$

$[\mathrm{kcal} / \mathrm{h}]=3657[\mathrm{kcal} / \mathrm{h}]$

b. qtransmisi Lantai

$=(0,018 / 0,25) \cdot(19 \cdot 3 \times 20) \cdot(30-$

$[\mathrm{kcal} / \mathrm{h}]=2802[\mathrm{kcal} / \mathrm{h}]$

c. qtransmisi Dinding 1

$=(0,018 / 0,15) \cdot(20 \times 8) \cdot(30-(-25))[\mathrm{kcal} / \mathrm{h}]$

$=1267[\mathrm{kcal} / \mathrm{h}]$ d. qtransmisi Dinding 2

$=(0,018 / 0,15) \cdot(20 \times 8) \cdot(35-(-25))[\mathrm{kcal} / \mathrm{h}]=$ $1267[\mathrm{kcal} / \mathrm{h}]$

e. qtransmisi Dinding 3

$=(0,018 / 0,15) \cdot(19 \cdot 3 \times 8) \cdot(35-(-25))[\mathrm{kcal} / \mathrm{h}]$

$=1223[\mathrm{kcal} / \mathrm{h}]$

f. qtransmisi Dinding 3

$=0,018 / 0,15) \cdot(19 \cdot 3 \times 8) \cdot(35-(-25))[\mathrm{kcal} / \mathrm{h}]$

$=1223[\mathrm{kcal} / \mathrm{h}]$

Jadi, total qtransmisi adalah 11349 $[\mathrm{kcal} / \mathrm{h}]$.

\subsection{Beban Infiltrasi}

Dengan menggunakan Tabel 1 berikut ini:

Tabel 1. Entalpi dan Massa Jenis Udara Berdasarkan Suhu [Stoecker, 1994]

\begin{tabular}{|c|c|c|}
\hline Temperature & Enthalpy & Density \\
\hline$[\mathbf{o C}]$ & {$[\mathrm{kcal} / \mathbf{k g}]$} & {$[\mathbf{k g} / \mathbf{m 3}]$} \\
\hline-45 & -10.788 & 0.6455 \\
\hline-40 & -9.566 & 0.6598 \\
\hline-35 & -8.331 & 0.6741 \\
\hline-30 & -7.073 & 0.6884 \\
\hline-25 & -5.778 & 0.7000 \\
\hline-20 & -4.432 & 0.7173 \\
\hline-15 & -3.000 & 0.7300 \\
\hline-10 & -1.452 & 0.7471 \\
\hline-5 & 0.35 & 0.7624 \\
\hline 0 & 2.261 & 0.7781 \\
\hline 5 & 4.45 & 0.7945 \\
\hline 10 & 7.009 & 0.8117 \\
\hline 15 & 10.057 & 0.8300 \\
\hline 20 & 13.745 & 0.4980 \\
\hline 25 & 18.269 & 0.8717 \\
\hline 30 & 23.882 & 0.8962 \\
\hline 35 & 30.913 & 0.9241 \\
\hline
\end{tabular}

Karena menggunakan satuan akhir pada perhitungan ini maka akan menggunakan persamaan (2):

$q$ inf $=\rho u, r \times V c s(h u-h u, r) . n \quad[\mathrm{kcal} / \mathrm{h}]$ (2).

Dengan menggunakan Tabel 1. dengan asumsi yang sama yaitu temperature luar ruangan $35 \mathrm{C}$ dan temperature ruangan Cold Storage 12, 25C, maka akan didapat beban infiltrasi:

$\mathrm{q}$ inf $=0,7000 \quad[\mathrm{~m} 3 / \mathrm{kg}] \quad \mathrm{x}$ (20x19.3x8.0) [m3] x (39.705) [kcal/m3] x $0.9 \mathrm{x} 1$ kali buka dalam 24 jam mengacu unjuk kerja pada design sheet. $=4598$ $[\mathrm{kcal} / \mathrm{h}]$. 


\subsection{Beban Kalor dari Operator}

Dengan menggunakan Tabel 2 berikut ini:

Tabel 2. Entalpi dan Massa Jenis Udara Berdasarkan Suhu [Stoecker, 1994]

\begin{tabular}{ccl}
\hline TEMP $(\mathrm{C})$ & \multicolumn{2}{c}{ HEAT FOR 1 MEN } \\
\hline-50 & 485 & $\mathrm{kcal} / \mathrm{h}$ \\
\hline-40 & 435 & $\mathrm{kcal} / \mathrm{h}$ \\
\hline-30 & 385 & $\mathrm{kcal} / \mathrm{h}$ \\
\hline-25 & 380 & $\mathrm{kcal} / \mathrm{h}$ \\
\hline-15 & 310 & $\mathrm{kcal} / \mathrm{h}$ \\
\hline 0 & 235 & $\mathrm{kcal} / \mathrm{h}$ \\
\hline
\end{tabular}

Berdasarkan Tabel 2, didapatkan laju kalor orang di ruangan bersuhu $-25 \mathrm{C}$ sebesar $380 \mathrm{kcal} / \mathrm{h}$. Jika, diasumsikan jumlah orang atau operator dalam memasukkan dan mengeluarkan produk dalam 8 jam per 24 jam/1hari sesuai unjuk kerja pada design sheet maka:

qoperator $=380 \mathrm{kcal} / \mathrm{h} \times 2 \times 8 / 24 \mathrm{jam}$

$$
=253 \mathrm{kcal} / \mathrm{h}
$$

\subsection{Beban Kalor dari Kipas}

Dengan asumsi beban kalor tiap kipas sebesar 1,5 kW dengan jumlah kipas sebanyak 2 buah yang bekerja selama 20 jama/hari maka:

qkipas $=1.5 \mathrm{~kW} \times 2 \times 860 \mathrm{kcal} / \mathrm{h}=$ $2150 \mathrm{kcal} / \mathrm{h}$

\subsection{Beban Kalor dari Pemanas Lantai}

Pemanas lantai yang digunakan memiliki beban kalor sebesar $0.66 \mathrm{~W}$ dengan jumlah total 6 buah.Dengan begitu didapatkan qpemanas lantai $=0.66 \mathrm{~kW} \mathrm{X}$ $6=3.96 \mathrm{~kW}=217 \mathrm{kcal} / \mathrm{h}$

\subsection{Beban Kalor dari Forklift}

Dengan asumsi beban kalor forklift sebesar $5,6 \mathrm{~kW}$ bekerja selama 8 jama/hari maka

qforklift $=5.6 \mathrm{~kW} \times 0.5 \times$

$8 / 24 \times 860 \mathrm{kcal} / \mathrm{h}=2150$

$\mathrm{kcal} / \mathrm{h}$

\subsection{Beban Kalor dari Lampu}

Seperti yang telah diketahui bahwa lampu yang dipakai berkekuatan $0.5 \mathrm{~kW}$ yang berjumlah 19 buah di setiap ruangan Cold Storage dimana lampu tersebut beroperasi selama $16 \mathrm{jam} / \mathrm{hari}$. Dengan begitu didapatkan. qlampu $=0.5 \mathrm{~kW} \mathrm{x}$ $19 \times 16 / 24 \times 860 \mathrm{kcal} / \mathrm{h}=2213$ $\mathrm{kcal} / \mathrm{h}$

\subsection{Beban Kalor dari Produk}

Waktu yang diperlukan untuk menurunkan temperatur Edamame (kedelai) dari temperature awal $-10^{\circ} \mathrm{C}$ ke temperatur akhir produk $-25^{\circ} \mathrm{C}$ ditentukan selama 24 jam, dimana $\mathrm{Cp}$ bibit jagung sebesar $1,7108 \mathrm{KJ} /\left(\mathrm{Kg} .{ }^{\circ} \mathrm{C}\right)$

$q_{\text {produk }}=\mathrm{m}_{\text {edamame }} \cdot \mathrm{Cp}_{\text {edamame. }} \cdot\left(\mathrm{T}_{\text {edamame }}\right)$ $[\mathrm{kcal} / \mathrm{h}]$

$=\quad 40000[\mathrm{~kg} / \mathrm{h}] \cdot 0,47[\mathrm{kcal} /(\mathrm{kg})] \cdot(-10-(-$

25))[C]

$=11750[\mathrm{kcal} / \mathrm{h}]$

Dari seluruh perhitungan bebanbeban yang ada, maka besarnya beban pendinginan pada cold storage 12, yang harus diberikan oleh evaporator untuk menjaga temperatur udara ruangan cold storage sebesar $-25^{\circ} \mathrm{C}$ adalah

qtotal $\mathrm{cs}=$ qtransmisi + qinfiltrasi+ qoperator + qkipas + qpemanas lantai + qlampu + qforklift + qproduk $=42,63 \mathrm{~kW}$

Mengacu pada perhitungan beban refrigerasi di Cold Storage 12, maka beban refrigerasi pada Cold Storage 13, Ante room dan Stuffing Room adalah sebesar: qtotal cold storage $13=26.23 \mathrm{~kW}$, qtotal ante room $=26.35 \mathrm{~kW}$, qstuffing room= $10.76 \mathrm{~kW}$, qtotal future $1=42.63 \mathrm{~kW}$, qtotal future $2=26.23 \mathrm{~kW}$

Sehingga, qtotal $=$ qtotal cold storage $12+$ qtotal cold storage $13+$ qtotal cs future $1+$ qtotal cs future $2+$ qtotal ante room + qstuffing room $=42.63 \mathrm{~kW}+26.23 \mathrm{~kW}+$ $42.63 \mathrm{~kW}+26.23 \mathrm{~kW}+26.35 \mathrm{~kW}+$ $10.76 \mathrm{~kW}=105.58 \mathrm{~kW}$.

\section{Pemilihan Kompresor Dengan Menggunakan MYCOM W 2016}

Dari berbagai jenis kompresor yang dapat dipilih maka dipilih kompresor 
dengan type Recipro N62WBHE sebanyak 2 unit (1unit sebagai back up ) dengan kapasitas $113.1 \mathrm{~kW}$, dan, jadi total daya yang diberikan compressor adalah sebesar 113.1 KW, karena nilai daya yang diperoleh pada perhitungan desain compressor adalah $105.58 \mathrm{KW}$, maka pemilihan compressor dengan type di atas sudah mewakili.

\section{KESIMPULAN}

Berdasarkan hasil penelitian dapat diperoleh kesimpulan sebagai berikut:

1. Penyegaran udara adalah suatu proses mendinginkan udara sehingga dapat mencapai temperature dan kelembaban yang sesuai dengan persyaratan kondisi udara dari sauatu ruangan tertentu yang dapat mengatur aliran udara dan kebersihannya

2. Berdasarkan hasil perhitungan dalam perancangan dan analisa diperoleh total refrigerasi sebesar $105.58 \mathrm{Kw}$

3. Pemilihan komponen pada system refrigerasi yaitu komponen compressor menggunakan aplikasi (software) My Com W versi 2016 Kompressor dengan type Recipro N62WBHE sebanyak 2 unit (1 Unit sebagai back up) dengan kapasitas $113.1 \mathrm{~kW}$.

\section{DAFTAR PUSTAKA}

[1] Al Haq, Z., Semadi Antara, Nyoman, Hartiati, Amna., 2015, Perancangan Tata Letak Ulang (Relayout) Pabrik Terhadap Tingkat Produksi Produk Bakso Ayam (Studi Kasus Pada Pabrik Bakso Ud. Supra Dinasty Denpasar). Jurnal Rekayasa Dan Manajemen Agroindustri, Vol. 3, No. 2, pp. 80-91

[2] Badarudin, A., 2010, Kajian Awal Sistem Kontrol Cold Storage Multi-Fungsi Menggunakan Perangkat Lunak Zeliosoft, Seminar Nasional IRWSN 2010, Bandung

[3] Merdiagung, Hari Prastowo dan Taufik Fajar Nugroho, 2014, Modifikasi Kinerja Cold Storage 10 Ton Menggunakan CFD (Computational Fluid Dynamic), Jurnal Teknik POMITS, Vol. 3, No. 1
[4] IEEE Std 519-1992, Recommendation Practice and Requirement for Harmonics Control in Electrical Power System, Revision of IEEE Std 519-1981

[5] Rahmat, M. R., 2015, Perancangan Cold Storage Untuk Produk Reagen, Jurnal Imiah Teknik Mesin, Vol. 3, No.1 Februari 2015, pp. 16-30

[6] Soebandrija, K. E. N, Sutanto, E. S., 2013, Analisis Distribution Center Pada Pt Anugrah Argon Medica Dengan Pendekatan Tata Letak Dan Fasilitas, Jurnal INASEA, Vol. 14 No.1, April 2013: 22-36

[7] Sinlae, Reny Navtalia, Suwiti, Ni Ketut, Suardana, I Wayan, 2015, Karakteristik Protein Dan Asam Amino Daging Sapi Bali Dan Wagyu Pada Penyimpanan Suhu Dingin $4^{\circ} \mathrm{C}$ (Characteristic Of Protein And Amino Acids Of Bali And Wagyu Beef At Cold Storage Temperature $4^{\circ} \mathrm{C}$ ). Buletin Veteriner Udayana, Vol. 7 No 2, Pp. 146-156

[8] Stoecker, WF dan Jerold W Jones, Supratman Hara. 1994. Refrigerasi dan Pengkondisian Udara Jilid 2 , Jakarta: Erlangga 